\title{
Sphingobacterium pedocola sp. nov. a novel halotolerant bacterium isolated from agricultural soil
}

\author{
Ákos Tóth · Ildikó Bata-Vidács · Judit Kosztik • Rózsa Máté • József Kutasi • \\ Erika Tóth · Károly Bóka • András Táncsics • István Nagy • Gábor Kovács • \\ József Kukolya
}

Received: 9 April 2021/Accepted: 17 July 2021/Published online: 6 August 2021

(C) The Author(s) 2021

\begin{abstract}
A Gram-reaction-negative halotolerant bacterial strain, designated $\mathrm{Ka} 21^{\mathrm{T}}$, was isolated from agricultural soil and characterised using a polyphasic approach to determine its taxonomic position. On the basis of $16 \mathrm{~S}$ rRNA gene sequence analysis, highest similarity was found with Sphingobacterium alkalisoli Y 3 L $14^{\mathrm{T}}(96.72 \%)$. Cells were observed to be aerobic, non-motile rods. The isolate was found to be able to grow between 0 and $10 \%$ of $\mathrm{NaCl}$ concentration. The assembled genome of strain $\mathrm{Ka} 21^{\mathrm{T}}$ has a total length of
\end{abstract}

Supplementary Information The online version contains supplementary material available at https://doi.org/10.1007/ s10482-021-01623-6.

Á. Tóth $(\bowtie)$ · I. Bata-Vidács · J. Kosztik · J. Kukolya Research Group for Food Biotechnology, Institute of Food Science and Technology, Hungarian University of Agriculture and Life Sciences, Budapest, Hungary e-mail: toth.akosgergely@gmail.com

\section{R. Máté · J. Kutasi}

BioFil Microbiological, Biotechnological and

Biochemical Ltd, Budapest, Hungary

E. Tóth

Department of Microbiology, Eötvös Loránd University, Budapest, Hungary

K. Bóka

Department of Plant Anatomy, Eötvös Loránd University, Budapest, Hungary
$5.2 \mathrm{Mb}$ with a $\mathrm{G}+\mathrm{C}$ content of $41.0 \mathrm{~mol} \%$. According to the genome analysis, $\mathrm{Ka} 21^{\mathrm{T}}$ encodes several glycoside hydrolases that may play a role in the degradation of accumulated plant biomass in the soil. Based on phenotypic characteristics and phylogenetic analysis, it is concluded that strain $\mathrm{Ka} 21^{\mathrm{T}}$ represents a novel species in the Sphingobacterium genus for which the name Sphingobacterium pedocola sp. nov. is proposed. The type strain of the species is strain $\mathrm{Ka} 21^{\mathrm{T}}\left(=\mathrm{LMG} 31575^{\mathrm{T}}=\right.$ NCAIM B. $\left.02636^{\mathrm{T}}\right)$.

\author{
A. Táncsics \\ Regional University Center of Excellence in \\ Environmental Industry, Szent István University, Gödöllő, \\ Hungary \\ I. Nagy · G. Kovács \\ SeqOmics Biotechnology Ltd., Mórahalom, Hungary \\ I. Nagy \\ Institute of Biochemistry, Biological Research Centre, \\ Eötvös Lorand Research Network, Szeged, Hungary \\ G. Kovács \\ University of Sopron, Sopron, Hungary
}


Keywords Bacteroidetes . New taxon ·

Sphingobacteriaceae $\cdot$ Sphingobacteriales .

Sphingobacterium pedocola

\begin{tabular}{|c|c|}
\hline \multicolumn{2}{|c|}{ Abbreviations } \\
\hline ANI & Average Nucleotide Identity \\
\hline dDDH & digital DNA-DNA hybridisation \\
\hline DSMZ & $\begin{array}{l}\text { Deutsche Sammlung von Mikroorganismen } \\
\text { und Zellkulturen (German Collection of } \\
\text { Microorganisms and Cell Cultures) }\end{array}$ \\
\hline GGDC & Genome-to-Genome Distance Calculator \\
\hline GNL & Aminoglycolipid \\
\hline $\mathrm{L}$ & Lipid \\
\hline $\begin{array}{l}\text { LB } \\
\text { agar }\end{array}$ & Luria-Bertani agar \\
\hline MiGA & Microbial Genomes Atlas \\
\hline MLSA & MultiLocus Sequence Analysis \\
\hline $\mathrm{PE}$ & Phosphatidylethanolamine \\
\hline PGL & Phosphoglycolipid \\
\hline PL & Phospholipid \\
\hline RAST & $\begin{array}{l}\text { Rapid Annotation using Subsystem } \\
\text { Technology }\end{array}$ \\
\hline TYGS & Type Strain Genome Server \\
\hline
\end{tabular}

\section{Introduction}

The genus Sphingobacterium was proposed by Yabuuchi et al. (1983), and it belongs to the family Sphingobacteriaceae, order Sphingobacteriales, class Sphingobacteriia, phylum 'Bacteroidetes' (Steyn et al. 1998). At the time of writing, the genus includes 60 validly published species with correct name (https://lpsn.dsmz.de/ June, 2021), the type species is Sphingobacterium spiritivorum (Euzéby 1997; Parte et al. 2020). The main characteristics of the genus are Gram-staining negative, catalase and oxidase positive, rod shaped, non-motile and MK-7 as predominant isoprenoid quinone. Most of the Sphingobacterium strains have been isolated from soil, rhizosphere or composts. In these environments, the decomposition of dead plant material is mediated by cellulolytic bacteria. The key enzymes in the lignocellulose degradation are the various glycoside hydrolases. Salttolerant enzymes may have advantages in many industrial applications (Oren 2010; Yin et al. 2015), particularly for utilisation in nonaqueous media (van den Burg 2003). The domain Bacteria contains many types of halophilic and halotolerant microorganisms. Although several classifications have been proposed, the most widely used definitions for these bacteria were formulated by Kushner (1978). Bacteria able to grow in the absence of salt as well as in the presence of relatively high salt concentrations are designated halotolerant (Ventosa et al. 1998). Here, we report a polyphasic taxonomical description of a novel, slightly halotolerant bacterium strain, designated $\mathrm{Ka} 21^{\mathrm{T}}$. The phenotypic, chemotaxonomic and genotypic properties indicate that strain $\mathrm{Ka} 21^{\mathrm{T}}$ represents a novel species within the genus Sphingobacterium, for which the name Sphingobacterium pedocola sp. nov. is proposed.

\section{Materials and methods}

Isolation and cultivation

Strain $\mathrm{Ka} 21^{\mathrm{T}}$ was isolated from an agricultural field in the Great Hungarian Plain. Before sampling, maize was harvested from the field. After sampling, the soil particles were homogenised by vortexing and serially diluted with peptone water $(9 \mathrm{~g}$ peptone, $1 \mathrm{~g} \mathrm{NaCl}$, in $1000 \mathrm{ml} \mathrm{dH_{2 }}$ O). $100-100 \mu \mathrm{l}$ of the third to the fifth member of the dilution series was subsequently spread onto xylan containing agar $\left(1 \mathrm{~g} \mathrm{NaNO}_{3} ; 1 \mathrm{~g} \mathrm{~K}_{2} \mathrm{HPO}_{4}\right.$; $3 \mathrm{~g} \mathrm{NaCl} ; 0.5 \mathrm{~g} \mathrm{MgCl}_{2} ; 0.5 \mathrm{~g}$ yeast extract; $0.5 \mathrm{~g}$

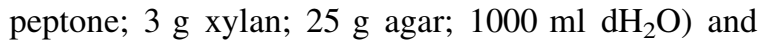
incubated at $10{ }^{\circ} \mathrm{C}$ for 5 days. Single colonies on the plates were purified on the same medium. The isolate was routinely maintained on LB medium (DSM medium No. 381, www.dsmz.de) at $28{ }^{\circ} \mathrm{C}$ and $\mathrm{pH}$ 7.5.

Physiology and chemotaxonomy

Biomass for chemical and molecular studies was obtained by cultivation in shaker flasks using LB medium at $30{ }^{\circ} \mathrm{C}$ for $32 \mathrm{~h}$. Colony morphology of strain $\mathrm{Ka} 21^{\mathrm{T}}$ was tested on LB agar medium by directly observing single colonies. Cell morphology of strain $\mathrm{Ka} 21^{\mathrm{T}}$ was observed by electron microscopy. The Gram reaction was determined with a nonstaining method as described by Buck (1982). Oxidase activity was studied with OXI oxidase test strip (Diagnostics s.r.o.). Catalase production was demonstrated by the method of Barrow and Feltham (2004). Growth at different temperatures (from 4 to $50{ }^{\circ} \mathrm{C}$ ), 
$\mathrm{NaCl}$ tolerance $(0-12 \%$ w/v) and $\mathrm{pH}$ tolerance $(\mathrm{pH}$ 4-10, using increments of $0.5 \mathrm{pH}$ units) were determined using LB medium. Acid production from different carbon sources, the assimilation of different substrates and the enzymatic activities of strain Ka $21^{\mathrm{T}}$ were investigated with API $50 \mathrm{CH}$, API $20 \mathrm{NE}$ and API ZYM kits (BioMérieux) according to the manufacturer's instructions. The API $50 \mathrm{CH}$ and $20 \mathrm{NE}$ tests were read after $24-48 \mathrm{~h}$ incubation at $30{ }^{\circ} \mathrm{C}$. Anaerobic and microaerophilic growth was checked on LB medium using the Anaerocult $\mathrm{A}$ and $\mathrm{C}$ systems (Merck).

Analyses of chemotaxonomic traits were carried out by DSMZ Identification Service (DSMZ, Braunschweig, Germany). The fatty acid profiles of strain $\mathrm{Ka} 21^{\mathrm{T}}$ was analysed on active growing cultures on LB agar. According to the DSMZ Identification Service, fatty acid methyl esters (FAMEs) were obtained following the methods of Miller (1982) and Kuykendall et al. (1988). FAMEs were separated by gas chromatography, detected by a flame ionisation detector using Sherlock Microbial Identification System (MIS) (MIDI, Microbial ID, Newark, DE 19711 U.S.A.) and identified by using the TSBA6 6.10 database of the Microbial Identification System. Summed feature components were identified thereafter by GC/MS.

The respiratory quinones were extracted from freeze dried material and purified by a silica-based solid phase extraction. Purified samples were further analysed by HPLC and UHPLC-ESI-qTOF system (Tindall 1990a, b; dsmz.de]. Polar lipids were studied according to Tindall et al. (Tindall 1990a, b; Tindall et al. 2007; dsmz.de).

\section{Genome features}

DNA was extracted from Ka $21^{\mathrm{T}}$ liquid culture grown in LB medium. Genomic DNA isolation and 16S rRNA gene amplification were performed according to Tóth et al. (2017). The genome of strain $\mathrm{Ka} 21^{\mathrm{T}}$ was sequenced with Illumina MiSeq sequencing technology as described previously (Szuroczki et al. 2019). Genome assembly was performed by SPAdes v. 3.9.1; CLC NGS Cell v. 11.0. Genome completeness and contamination values were examined by TypeMet tool of MiGA server (http://microbial-genomes.org/) (Rodriguez et al. 2018). Annotation of the genome was performed by NCBI Prokaryotic Genome Annotation
Pipeline v4.4 with Best-placed reference protein set and GeneMarkS + methods (Tatusova et al. 2016; O'Leary et al. 2016) and Rapid Annotation using Subsystem Technology server v. 2.0 (RAST; https:// rast.nmpdr.org) (Aziz et al. 2008).

The anti-SMASH server was used to identify the secondary metabolite biosynthesis gene clusters (Blin et al. 2019). Comparative genome analysis for Sphingobacterium pedocola $\mathrm{Ka}^{\mathrm{T}}{ }^{\mathrm{T}}$, Sphingobacterium alkalisoli $\mathrm{Y} 3 \mathrm{~L} 14^{\mathrm{T}}$ (Xu et al. 2017), Sphingobacterium olei HAL-9 ${ }^{\mathrm{T}}$ (Liu et al. 2020) and Sphingobacterium composti DSM $18850^{\mathrm{T}}$ (Yoo et al. 2007, later homonym of Sphingobacterium composti $\mathrm{T} 5-12^{\mathrm{T}}$ (Ten et al. 2006)) was performed by OrthoVenn2 webserver (https://orthovenn2.bioinfotoolkits.net/) (Xu et al. 2019). Methabolic pathways were analysed using the MicroScope platform (Vallenet et al. 2009).

\section{Phylogeny}

The partial 16S rRNA gene sequence of strain Ka2 $1^{\mathrm{T}}$ was compared with the EzTaxon EzBioCloud Database (http://www.ezbiocloud.net/taxonomy) (Kim et al. 2012) for an approximate phylogenetic affiliation. After Sanger sequencing of the 16S rRNA gene, a genome sequencing project of $\mathrm{Ka} 21^{\mathrm{T}}$ was carried out, which revealed that there is only one $16 \mathrm{~S}$ rRNA gene copy in the genome. Phylogenetic tree based on $16 \mathrm{~S}$ rRNA gene was inferred by using the Maximum Likelihood method and Kimura 2-parameter model (Kimura 1980). The tree with the highest log likelihood $(-18,693.12)$ is shown in Fig. 3. Initial trees for the heuristic search were obtained automatically by applying Neighbor-Join and BioNJ algorithms to a matrix of pairwise distances estimated using the Maximum Composite Likelihood (MCL) approach, and then selecting the topology with superior $\log$ likelihood value. There were a total of 1491 positions in the final dataset. Evolutionary analyses were conducted in MEGA X (Kumar et al. 2018). For phylogenomic studies TYGS (https://tygs.dsmz.de/) (Meier-Kolthoff and Göker 2019), MiGA (http:// microbial-genomes.org/) (Rodriguez et al. 2018) and GGDC (http://ggdc.dsmz.de/) (Meier-Kolthoff et al. 2013) webservers were used. 


\section{Results and discussion}

Phenotypic and biochemical characterisation

LB medium was used for general laboratory cultivation, but the novel strain also grows well on TSA, nutrient and R2A media. After $72 \mathrm{~h}$ growth on LB agar at $30{ }^{\circ} \mathrm{C}$, colonies were observed to be $1.0-1.5 \mathrm{~mm}$ in diameter, circular, non-mucoid, smooth and yellow. Strain Ka $21^{\mathrm{T}}$ was found to be Gram-reaction-negative, oxidase and catalase positive aerobic bacterium. Cells are non-motile, grow in $0.0-10.0 \%(\mathrm{w} / \mathrm{v}) \mathrm{NaCl}$, at a $\mathrm{pH}$ range from 6.5 to 9.0 and at temperatures between 10 and $35{ }^{\circ} \mathrm{C}$. Optimal growth was observed at $30{ }^{\circ} \mathrm{C}$, $1 \%(\mathrm{w} / \mathrm{v}) \mathrm{NaCl}$ and $\mathrm{pH}$ 8.0. Cells of $\mathrm{Ka} 21^{\mathrm{T}}$ are short rods, the mean cell size is $0.5-0.7 \mu \mathrm{m}$ in width and 1.5-2.0 $\mu \mathrm{m}$ in length (Online resource 1). According to API $50 \mathrm{CH}$ test, $\mathrm{Ka} 21^{\mathrm{T}}$ produces acid from $\mathrm{L}^{-}$ arabinose, D-xylose, D-glucose, D-mannose, esculin, and D-trehalose. Assimilation of D-glucose, L-arabinose, D-mannose, N-Acetyl-Glucosamine and D-maltose, hydrolysis of esculin and $\beta$-galactosidase activity were demonstrated by using the API 20 NE test. In the API ZYM test, strain $\mathrm{Ka} 21^{\mathrm{T}}$ showed activities of alkaline phosphatase, esterase lipase (C8), leucine arylamidase, naphthol-AS-BI-phosphohydrolase, $\beta$ glucosidase $\alpha$-glucosidase, and $\mathrm{N}$-acetyl- $\beta$-glucosaminidase. Distinctive physiological and biochemical characteristics of the isolate are given in Table 1 .

\section{Chemotaxonomic characteristics}

The predominant cellular fatty acids of strain $\mathrm{Ka}_{2} 1^{\mathrm{T}}$ are summed feature $3\left(\mathrm{C}_{16: 1} \omega 7 c / \mathrm{C}_{16: 1} \omega 6 c, 33.6 \%\right)$, iso- $\mathrm{C}_{15: 0}(32.5 \%)$ and iso- $\mathrm{C}_{17: 0} 3 \mathrm{OH}(20.5 \%)$. The fatty acid profile is similar to that of related strains, in accordance with the description of Sphingobacterium genus (Steyn et al. 1998). However, the ratios of the different components are different. The complete fatty acid composition is shown in Table 2. The only respiratory quinone of $\mathrm{Ka}_{2} 1^{\mathrm{T}}$ is menaquinone-7 (MK7). Strain Ka $21^{\mathrm{T}}$ exhibits a complex polar lipid profile consisting of phosphatidylethanolamine (PE) and phosphoglycolipid (PGL) as dominant elements, one aminoglycolipid (GNL), six phospholipids (PL) and six uncharacterised lipids (L) (Online resource 2).
Whole genome sequence analysis

The completeness and contamination values of the genome are $97.2 \%$ and $0.9 \%$, respectively. Other quality labels of genome sequencing and assembly are as follows: 270-fold genome coverage, contig $\mathrm{N} 50=433,102$, number of contigs are 27 . The genome size and $\mathrm{G}+\mathrm{C}$ content of $\mathrm{Ka} 21^{\mathrm{T}}$ are $5,205,271 \mathrm{bp}$ and $41.0 \mathrm{~mol} \%$, respectively. According to the annotation, there are 4320 genes, $4260 \mathrm{CDSs}$ and 60 RNA genes in the genome. The coding density is $89.33 \%$.

The RAST analysis revealed the presence of 242 subsystems, the subsystem coverage was $20 \%$ (Online resource 3 ).

The genome of $\mathrm{Ka} 21^{\mathrm{T}}$ contains 5 putative biosynthetic gene clusters (terpene, furan, arylpolyene, resorcinol, and type III polyketide synthase) in 4 genomic regions.

Using the genome annotation and the Pfam database (Mistry et al. 2020; http://pfam.xfam.org/), several glycoside hydrolase $(\mathrm{GH})$ genes in various $\mathrm{GH}$ families were found. These enzyme genes may play a role in the breakdown and modification of carbohydrates in soil. Some of the enzymes (in parentheses are the GenBank accession numbers) belonging to the GH1 (MBE8721502), GH2 (MBE8721947, MBE8722219, MBE8722220, MBE8720458), GH3 (MBE8720457, MBE8722817), GH9 (MBE8722726), GH10 (MBE8720362, MBE8720375, MBE8722731), GH16 (MBE8722218), GH26 (MBE8722637), GH43 (MBE8721705, MBE8721946, MBE8722218, MBE8721706, MBE8720364, MBE8720363) and GH130 (MBE8722632) families are active on plant cell wall polysaccharides (http://www.cazy.org/) (Lombard et al. 2014). These hydrolase genes are located on six contigs (number 15, 19, 20, 21, 22, 23) in the genome of $\mathrm{Ka}_{2} 1^{\mathrm{T}}$ and in the most cases, an island-like arrangement was found. Due to the complex structure of plant cell wall, its deconstruction needs collective work of several enzymes. Coordinated regulation of closely located genes may result in more efficient degradation. For example, on the contig 15, a region containing four GH genes (MBE8720362: 1,4-beta-xylanase; MBE8720363 and MBE8720364: alpha-N-arabinofuranosidase, MBE8720375: endo1,4-beta-xylanase) that potentially play a role in xylan degradation was identified (Fig. 1). 
Table 1 Differential characteristics of $\mathrm{Ka}_{2} 1^{\mathrm{T}}$ and the closely related strains

\begin{tabular}{|c|c|c|c|c|}
\hline & 1 & $2^{\mathrm{a}}$ & $3^{\mathrm{a}}$ & 4 \\
\hline Isolation source & Soil & Soil & Soil & Compost \\
\hline Temperature range for growth $\left(^{\circ}\right.$ & $10-35(30)$ & $10-35(30)$ & $10-40(30)$ & $10-45(40)$ \\
\hline \multicolumn{5}{|l|}{ C) (optimum) } \\
\hline Growth with $\mathrm{NaCl}$ (optimum) (\%) & $0-10(1)$ & $0-5(1)$ & $0-6(1)$ & $0-6(0)$ \\
\hline $\mathrm{pH}$ range for growth (optimum) & $6.5-9.0(8.0)$ & $6.0-10.0(7.0)$ & $6.0-10.0(8.0)$ & $6.0-9.0(8.0)$ \\
\hline Oxidase activity & + & + & - & + \\
\hline \multicolumn{5}{|l|}{ Utilisation of } \\
\hline L-arabinose & + & - & + & + \\
\hline D-mannose & + & - & + & + \\
\hline D-mannitol & - & - & + & - \\
\hline Capric acid & - & + & - & - \\
\hline Trisodium citrate & - & + & - & - \\
\hline \multicolumn{5}{|l|}{ Activity of } \\
\hline Urease & - & - & + & - \\
\hline Valine arylamidase & - & + & - & + \\
\hline Cystine arylamidase & - & + & - & - \\
\hline$\alpha$-Chymotrypsin & - & - & + & - \\
\hline$\beta$-Galactosidase & - & - & + & - \\
\hline$\alpha$-Mannosidase & - & - & + & - \\
\hline esterase lipase (C8) & + & - & + & + \\
\hline DNA G $+\mathrm{C}$ content $(\mathrm{mol} \%)$ & 41.0 & 40.6 & 36.0 & $42.3^{\mathrm{a}}$ \\
\hline
\end{tabular}

Strains: 1, Ka21 ${ }^{\mathrm{T}}$; 2, Sphingobacterium olei HAL-9 ${ }^{\mathrm{T}}$ (Liu et al. 2020); 3, Sphingobacterium alkalisoli $\mathrm{Y} 3 \mathrm{~L} 14^{\mathrm{T}}$ (Xu et al. 2017); 4, Sphingobacterium composti DSM $18850^{\mathrm{T}}$ (Yoo et al. 2007)

${ }^{\mathrm{a}}$ Data are from Liu et al. (2020) and Yoo et al. (2007) for the G + C content of Sphingobacterium composti DSM 18850 ${ }^{\mathrm{T}}$

Table 2 Cellular fatty acid composition of $\mathrm{Ka} 21^{\mathrm{T}}$ and related Sphingobacterium strains

\begin{tabular}{|c|c|c|c|c|}
\hline & 1 & 2 & $3^{\mathrm{a}}$ & $4^{\mathrm{a}}$ \\
\hline $\mathrm{C}_{14: 0}$ & $\operatorname{tr}$ & $\operatorname{tr}$ & 1.2 & $\operatorname{tr}$ \\
\hline iso- $\mathrm{C}_{15: 0}$ & 32.5 & 28.3 & 31.9 & 44.3 \\
\hline iso- $\mathrm{C}_{15: 0} 3 \mathrm{OH}$ & 2.3 & 2.2 & 2.3 & 1.9 \\
\hline anteiso- $\mathrm{C}_{15: 0}$ & $\operatorname{tr}$ & - & $\operatorname{tr}$ & $\operatorname{tr}$ \\
\hline $\mathrm{C}_{16: 0}$ & 1.2 & 4.7 & 4.4 & 3.1 \\
\hline $\mathrm{C}_{16: 0} 3 \mathrm{OH}$ & $\operatorname{tr}$ & $\operatorname{tr}$ & 2.2 & $\operatorname{tr}$ \\
\hline $\mathrm{C}_{18: 1} \omega 9 c$ & - & - & 1.3 & 1.5 \\
\hline iso- $\mathrm{C}_{17: 0} 3 \mathrm{OH}$ & 20.5 & 17.6 & 13.7 & 17.3 \\
\hline Summed feature $3\left(\mathrm{C}_{16: 1} \omega 7 c / \mathrm{C}_{16: 1} \omega 6 c\right)$ & 33.6 & 40.1 & 38.9 & 25.6 \\
\hline Summed feature 9 (iso- $\mathrm{C}_{17: 1} \omega 9 c / \mathrm{C}_{16: 0} 10$-methyl) & 3.4 & 1.4 & $\operatorname{tr}$ & 1.6 \\
\hline
\end{tabular}

Strains: 1, Ka21 ${ }^{\mathrm{T}}$; 2, Sphingobacterium composti DSM 18850 ${ }^{\mathrm{T}}$ (Yoo et al. 2007); 3, Sphingobacterium olei HAL-9 ${ }^{\mathrm{T}}$ (Liu et al. 2020); 4, Sphingobacterium alkalisoli $\mathrm{Y} 3 \mathrm{~L} 14^{\mathrm{T}}$ (Xu et al. 2017). tr, trace amount $(<1 \%)$; - , not detected

${ }^{a}$ Data are from Liu et al. (2020) 


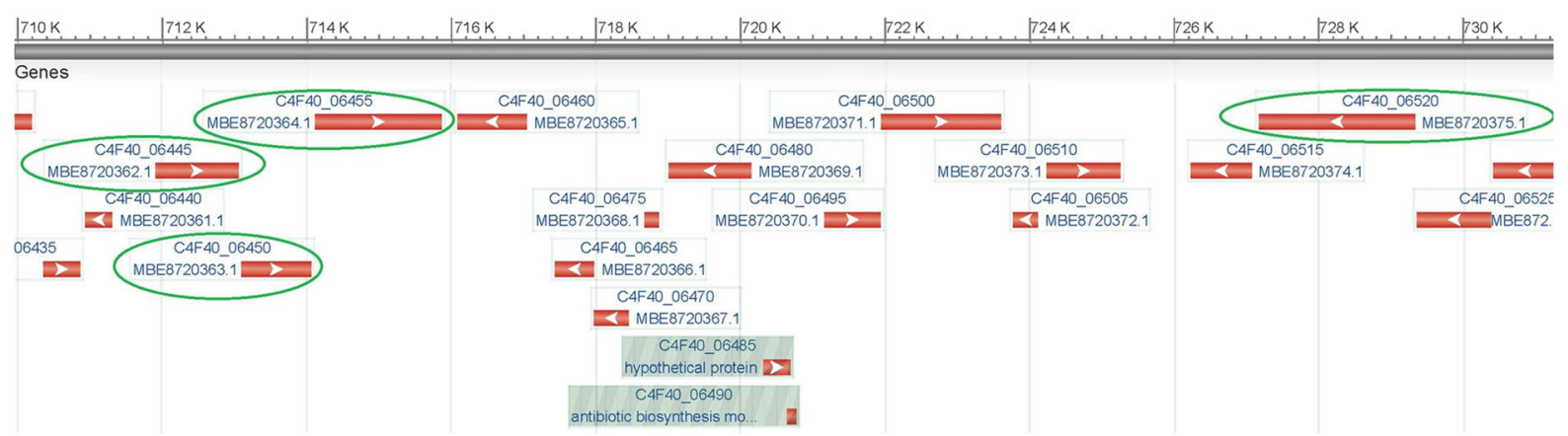

Fig. 1 Island-like topology of four glycoside hydrolase genes (MBE8720362: 1,4-beta-xylanase; MBE8720363 and MBE8720364: alpha-N-arabinofuranosidase, MBE8720375: endo-1,4-beta-xylanase) involved in xylan degradation. The

The comparative genome analysis for Sphingobacterium pedocola $\mathrm{Ka} 21^{\mathrm{T}}$, Sphingobacterium alkalisoli Y3L14 ${ }^{\mathrm{T}}$, Sphingobacterium olei HAL- ${ }^{\mathrm{T}}$ and Sphingobacterium composti DSM $18850^{\mathrm{T}}$ revealed that the strains form 4264 clusters, 2051 orthologous clusters (at least contains two species) and 2213 single-copy gene clusters (Fig. 2). Methabolic pathway analysis revealed the elements of ppGpp biosynthesis (pathway completion value is 0.83 ), which nucleotide plays key

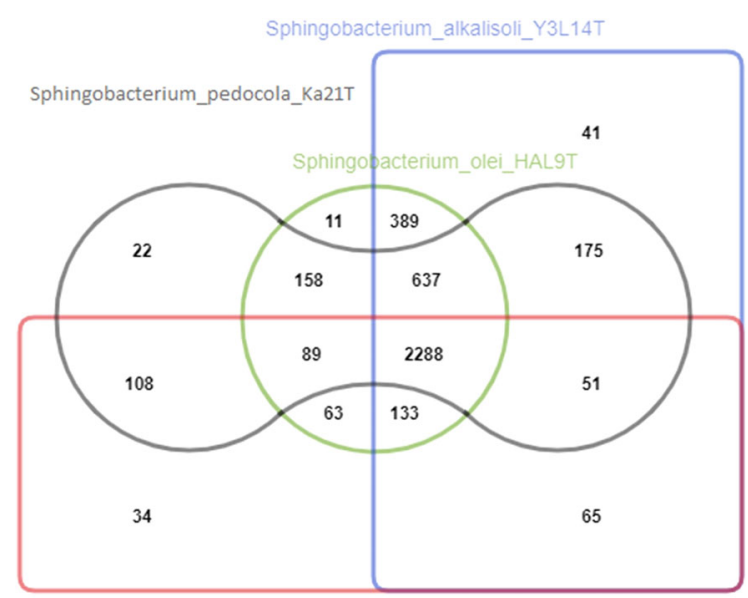

Sphingobacterium_composti_DSM_18850T

Fig. 2 Comparative genome analysis for Sphingobacterium pedocola $\mathrm{Ka} 21^{\mathrm{T}}$, Sphingobacterium alkalisoli $\mathrm{Y} 3 \mathrm{~L} 14^{\mathrm{T}}$, Sphingobacterium olei HAL-9 ${ }^{\mathrm{T}}$ and Sphingobacterium composti DSM $18850^{\mathrm{T}}$ was performed by OrthoVenn 2 webserver. The numbers in the Venn-Diagram represent the number of clusters shared between strains. OrthoVenn2 generates clusters of proteins where each cluster consists of orthologs or paralogs from species. The overlapping cluster means the cluster contains proteins from different species figure shows the region of contig 15 from 710 to $740 \mathrm{kbp}$. The arrows indicate the direction of genes. The codes above the arrows indicate the locus tags

role in the stress signalling system referred to as stringent response (Irving et al. 2021).

Phylogenetic analysis

According to the comparisons with the partial (1343 bp) 16S rRNA gene sequences in the EzTaxon database, highest level of sequence similarity occurred with Sphingobacterium alkalisoli $\mathrm{Y}^{2} \mathrm{~L}_{14}{ }^{\mathrm{T}}(96.72 \%)$ (Xu et al. 2017), Sphingobacterium olei HAL-9 ${ }^{\mathrm{T}}$ $(96.35 \%)$ (Liu et al. 2020) and Sphingobacterium composti DSM $18850^{\mathrm{T}}$ (95.23\%) (Yoo et al. 2007). The 16S rRNA gene based phylogeny tree suggests that strain $\mathrm{Ka} 21^{\mathrm{T}}$ forms a distinct phyletic lineage within Sphingobacterium genus (Fig. 3).

According to genome based analysis, the closely related taxons found by MiGA are Sphingobacterium olei HAL-9 ${ }^{\mathbf{T}}$ (GenBank assembly accession: GCA_005048855) (86.5\% ANI) and Sphingobacterium alkalisoli $\mathrm{Y} 3 \mathrm{~L} 14^{\mathrm{T}}$ (GenBank assembly accession: GCA_005049105) (84.39\% ANI). The p-value of taxonomic novelty at species level is 0.00292 .

dDDH values (identities/HSP length) between $\mathrm{Ka} 21^{\mathrm{T}}$ and Sphingobacterium olei HAL- ${ }^{\mathbf{T}}$ and $\mathrm{Ka} 21^{\mathrm{T}}$ and Sphingobacterium alkalisoli $\mathrm{Y} 3 \mathrm{~L} 14^{\mathrm{T}}$ are $31.60 \%$ and $28.20 \%$, respectively. Whole genome based tree generated by TYGS also confirmed the taxonomic position of $\mathrm{Ka} 21^{\mathrm{T}}$ within Sphingobacterium genus as a novel species (Fig. 4).

According to the $16 \mathrm{~S}$ rRNA based and whole genome based phylogenetic analyses, $\mathrm{Ka} 21^{\mathrm{T}}$ represents a novel species in genus Sphingobacterium. The generally accepted species boundary for 16S rRNA gene similarity, ANI and dDDH values are $98.7 \%$, 


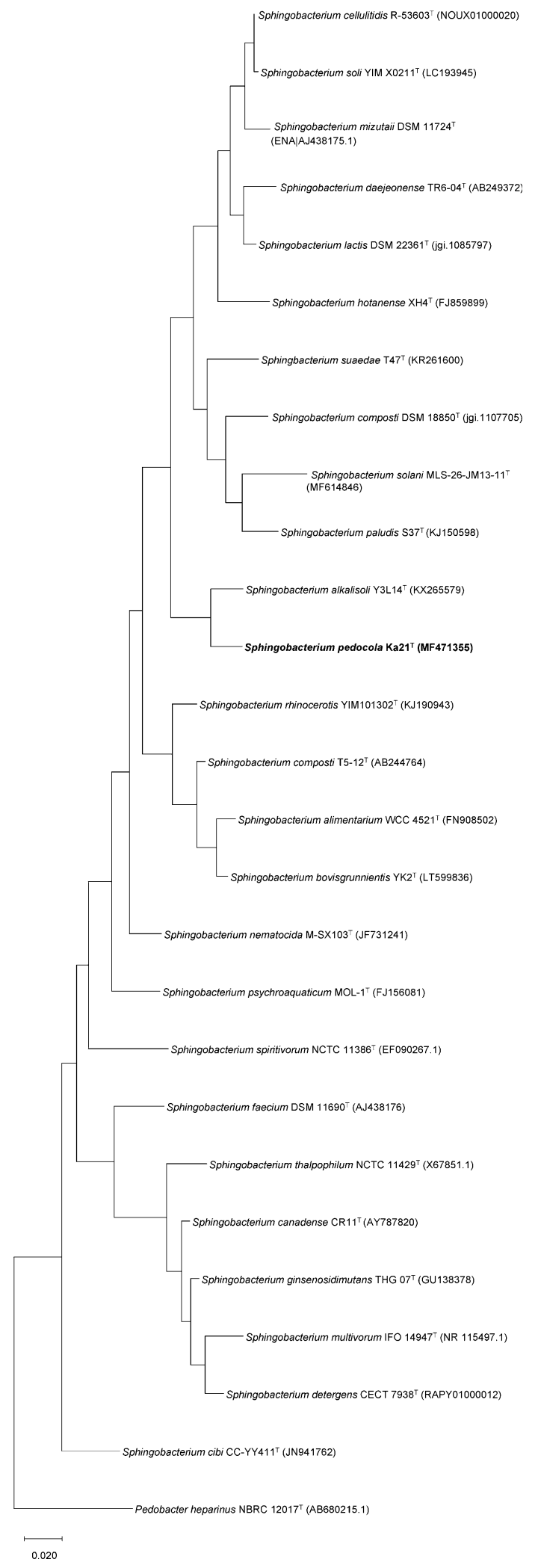

4Fig. 3 Maximum-likelihood tree based on 16S rRNA gene sequences showing the phylogenetic relationships between strain $\mathrm{Ka} 21^{\mathrm{T}}$ and related taxa

95-96\% and 70\%, respectively (Meier-Kolthoff et al. 2013; Chun et al. 2018; Stackebrandt and Ebers 2006; Goris et al. 2007; Richter and Rosselló-Móra 2009). Obtained values for $\mathrm{Ka} 21^{\mathrm{T}}(96.72 \%$ for $16 \mathrm{~S}$ rRNA gene similarity, $86.5 \%$ for ANI and $31.6 \%$ for dDDH) are all lower, confirming the results of phylogenetic treeing.

\section{Protologue}

In conclusion, the revealed characteristics of Ka2 $1^{\mathrm{T}}$ exhibit the typical traits of the genus Sphingobacterium: Gram-negative, non-motile and rod shaped cells, positive for catalase and oxidase, MK-7 as respiratory quinone, major amount of phosphatidylethanolamine in the polar lipid profile, fatty acid profile with $\mathrm{C}_{16: 1} \omega 7 c / \mathrm{C}_{16: 1} \omega 6 c$, iso- $\mathrm{C}_{15: 0}$, iso$\mathrm{C}_{17: 0} 3 \mathrm{OH}$ as the most dominant compounds and low genomic $\mathrm{G}+\mathrm{C}$ content. According to $16 \mathrm{~S}$ rRNA gene and whole genome based phylogenetic trees, strain $\mathrm{Ka} 21^{\mathrm{T}}$ occupies a separate lineage in the genus. The 16S rRNA gene sequence similarities to the closely related taxons and overall genome related indices (ANI, dDDH) also indicate its distance from other species. Phenotypic, biochemical, chemotaxonomic and phylogenetic information of strain Ka $21^{\mathrm{T}}$ support its classification as a novel species of Sphingobacterium, for which the name Sphingobacterium pedocola sp. nov. is proposed. The GenBank accession numbers for the 16S rRNA gene sequence and the whole genome of Sphingobacterium pedocola strain $\mathrm{Ka} 21^{\mathrm{T}}$ are MF471355 and PSKQ00000000, respectively.

\section{Description of Sphingobacterium pedocola sp. nov.}

Sphingobacterium pedocola (pe.do'co.la. Gr. neut. n. pedon soil; L. suff. -cola inhabiting; N.L. n. pedocola soil-inhabiting). Cells are strictly aerobic, Gramreaction-negative straight rods and non-motile. It grows well on TSA, LB, nutrient and R2A plates. Colonies have yellow pigmentation on LB after $72 \mathrm{~h}$ 


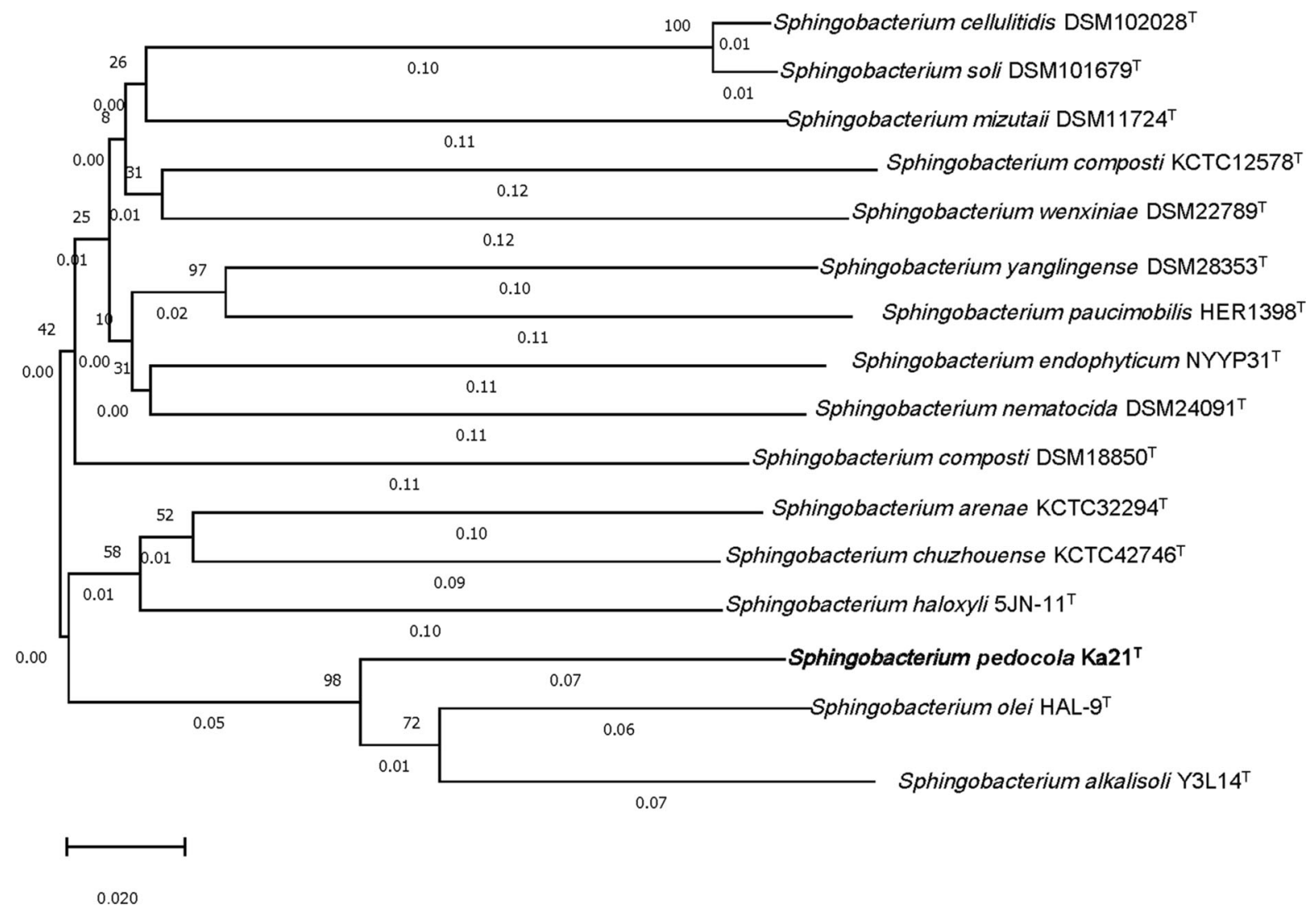

Fig. 4 Tree inferred with FastME 2.1.6.1 (Lefort et al. 2015) from GBDP distances calculated from genome sequences. The branch lengths are scaled in terms of GBDP distance formula 5 . The numbers above branches are GBDP pseudo-bootstrap

incubation. Cells are $0.5-0.7 \mu \mathrm{m}$ in width and $1.5-2.0 \mu \mathrm{m}$ in length. It grows at $10-35^{\circ} \mathrm{C}$ (optimum, $30{ }^{\circ} \mathrm{C}$ ) and at $\mathrm{NaCl}$ concentrations of $0.0-10.0 \mathrm{w} / \mathrm{v} \%$ (optimum, $1 \mathrm{w} / \mathrm{v} \%$ ). The major fatty acids are summed feature $3\left(\mathrm{C}_{16: 1} \omega 7 \mathrm{c} / \mathrm{C}_{16: 1} \omega 6 c\right)$, iso- $\mathrm{C}_{15: 0}$ and iso- $\mathrm{C}_{17: 0}$ $3 \mathrm{OH}$. The only respiratory quinone is MK-7. The major polar lipids are phosphatidylethanolamine and phosphoglycolipid. The DNA G $+\mathrm{C}$ content of the type strain is $41.0 \mathrm{~mol} \%$. The type strain is $\mathrm{Ka} 21^{\mathrm{T}}$ (= LMG $31575=$ NCAIM B.02636) isolated from agricultural field in the Great Hungarian Plain, Hungary.

Funding Open access funding provided by Hungarian University of Agriculture and Life Sciences. This work was supported by the NVKP_16-1-2016-0009 Project. Ákos Tóth was supported by the János Bolyai Research Scholarship of the Hungarian Academy of Sciences. Funding was provided by Magyar Tudományos Akadémia (Grant No. BO/00342/18). support values from 100 replications, with an average branch support of $39.9 \%$. The tree was rooted at the midpoint (Farris 1972)

Availability of data and material The GenBank accession numbers for the 16S rRNA gene sequence and the whole genome of Sphingobacterium pedocola strain $\mathrm{Ka}^{2} 1^{\mathrm{T}}$ are MF471355 and PSKQ00000000, respectively.

\section{Declarations}

Conflict of interest The authors declare that they have no conflict of interest.

Open Access This article is licensed under a Creative Commons Attribution 4.0 International License, which permits use, sharing, adaptation, distribution and reproduction in any medium or format, as long as you give appropriate credit to the original author(s) and the source, provide a link to the Creative Commons licence, and indicate if changes were made. The images or other third party material in this article are included in the article's Creative Commons licence, unless indicated otherwise in a credit line to the material. If material is not included in the article's Creative Commons licence and your intended use is not permitted by statutory regulation or exceeds the permitted use, you will need to obtain permission directly 
from the copyright holder. To view a copy of this licence, visit http://creativecommons.org/licenses/by/4.0/.

\section{References}

Aziz RK, Bartels D, Best AA, DeJongh M, Disz T, Edwards RA, Formsma K, Gerdes S, Glass EM, Kubal M, Meyer F, Olsen GJ, Olson R, Osterman AL, Overbeek RA, McNeil LK, Paarmann D, Paczian T, Parrello B, Pusch GD, Reich C, Stevens R, Vassieva O, Vonstein V, Wilke A, Zagnitko O (2008) The RAST server: rapid annotations using subsystems technology. BMC Genom 9:75

Barrow GI, Feltham RKA (2004) Cowan and steel's manual for the identification of medical bacteria, 3rd edn. Cambridge University Press, Cambridge

Blin K, Shaw S, Steinke K, Villebro R, Ziemert N, Lee SY, Medema MH, Weber T (2019) antiSMASH 5.0: updates to the secondary metabolite genome mining pipeline. Nucl Acids Res 47:81-87

Buck JD (1982) Nonstaining (KOH) method for determination of Gram reactions of marine bacteria. Appl Environ Microbiol 44:992-993

Chun J, Oren A, Ventosa A, Christensen H, Arahal DR, da Costa MS (2018) Proposed minimal standards for the use of genome data for the taxonomy of prokaryotes. Int $\mathbf{J}$ Syst Evol Microbiol 68:461-466

Euzéby JP (1997) List of bacterial names with standing in nomenclature: a folder available on the internet. Int J Syst Bacteriol 47:590-592

Farris JS (1972) Estimating phylogenetic trees from distance matrices. Am Nat 106:645-667

Goris J, Konstantinidis KT, Klappenbach JA, Coenye T, Vandamme P, Tiedje TM (2007) DNA-DNA hybridization values and their relationship to whole-genome sequence similarities. Int J Syst Evol Microbiol 57:81-91

Irving SE, Choudhury NR, Corrigan RM (2021) The stringent response and physiological roles of (pp)pGpp in bacteria. Nat Rev Microbiol 19:256-271

Kim OS, Cho YJ, Lee K, Yoon SH, Kim M, Na H, Park SC, Jeon YS, Lee JH, Yi H, Won S, Chun J (2012) Introducing EzTaxon-e: a prokaryotic 16S rRNA gene sequence database with phylotypes that represent uncultured species. Int J Syst Evol Microbiol 62:716-721

Kimura M (1980) A simple method for estimating evolutionary rate of base substitutions through comparative studies of nucleotide sequences. J Mol Evol 16:111-120

Kumar S, Stecher G, Li M, Knyaz C, Tamura K (2018) MEGA $\mathrm{X}$ : molecular evolutionary genetics analysis across computing platforms. Mol Biol Evol 35:1547-1549

Kushner DJ (1978) Life in high salt and solute concentrations: halophilic bacteria. In: Kushner DJ (ed) Microbial life in extreme environments. Academic Press, Ltd., London, pp 317-368

Kuykendall LD, Roy MA, O’Neill JJ, Devine TE (1988) Fatty acids, antibiotic resistance, and deoxyribonucleic acid homology groups of Bradyrhizobium japonicum. Int J Syst Evol Microbiol 38:358-361
Lefort V, Desper R, Gascuel O (2015) FastME 2.0: a comprehensive, accurate, and fast distance-based phylogeny inference program. Mol Biol Evol 32:2798-2800

Liu B, Yang X, Sheng M, Yang Z, Qiu J, Wang C, He J (2020) Sphingobacterium olei sp. nov., isolated from oil-contaminated soil. Int J Syst Evol Microbiol 70:1931-1939

Lombard V, Golaconda RH, Drula E, Coutinho PM, Henrissat B (2014) The carbohydrate-active enzymes database (CAZy) in 2013. Nucl Acids Res 42:D490-D495

Meier-Kolthoff JP, Göker M (2019) TYGS is an automated high-throughput platform for state-of-the-art genomebased taxonomy. Nat Commun 10:2182

Meier-Kolthoff JP, Auch AF, Klenk HP, Göker M (2013) Genome sequence-based species delimitation with confidence intervals and improved distance functions. BMC Bioinform 14:60

Miller LT (1982) A single derivatization method for bacterial fatty acid methyl esters including hydroxy acids. J Clin Microbiol 16:584-586

Mistry J, Chuguransky S, Williams L, Qureshi M, Salazar GA, Sonnhammer ELL, Tosatto SCE, Paladin L, Raj S, Richardson LJ, Finn RD, Bateman A (2020) Pfam: the protein families database in 2021. Nucl Acids Res 49:D412-D419

O'Leary NA, Wright MW, Brister JR, Ciufo S, Haddad D et al (2016) Reference sequence (RefSeq) database at NCBI: current status, taxonomic expansion, and functional annotation. Nucl Acids Res 4:D733-D745

Oren A (2010) Industrial and environmental applications of halophilic microorganisms. Environ Technol 31(8-9):825-834. https://doi.org/10.1080/ 09593330903370026

Parte AC, Sardà Carbasse J, Meier-Kolthoff JP, Reimer LC, Göker M (2020) List of prokaryotic names with standing in nomenclature (LPSN) moves to the DSMZ. Int J Syst Evol Microbiol 70:5607-5612

Richter M, Rosselló-Móra R (2009) Shifting the genomic gold standard for the prokaryotic species definition. Proc Natl Acad Sci USA 106:19126-19131

Rodriguez RLM, Gunturu S, Harvey WT, Rosselló-Mora R, Tiedje JM, Cole JR, Konstantinidis KT (2018) The Microbial genomes atlas (MiGA) webserver: taxonomic and gene diversity analysis of Archaea and Bacteria at the whole genome level. Nucl Acids Res 46:W282-W288

Stackebrandt E, Ebers J (2006) Taxonomic parameters revisited: tarnished gold standards. Microbiol Today 33:152-155

Steyn PL, Segers P, Vancanneyt M, Sandra P, Kersters K, Joubert JJ (1998) Classification of heparinolytic bacteria into a new genus, Pedobacter, comprising four species: Pedobacter heparinus comb. nov., Pedobacter piscium comb. nov., Pedobacter africanus sp. nov. and Pedobacter saltans sp. nov. proposal of the family Sphingobacteriaceae fam. nov. Int J Syst Bacteriol 48:165-177

Szuroczki S, Khayer B, Sproer C, Toumi M, Szabo A, Felfoldi T, Schumann P, Toth E (2019) Arundinibacter roseus gen. nov., sp. nov., a new member of the family Cytophagaceae. Int J Syst Evol Microbiol 69:2076-2081

Tatusova T, DiCuccio M, Badretdin A, Chetvernin V, Nawrocki EP, Zaslavsky L, Lomsadze A, Pruitt KD, Borodovsky M, Ostell J (2016) NCBI prokaryotic genome annotation pipeline. Nucl Acids Res 44:6614-6624 
Ten LN, Liu Q-M, Im W-T, Aslam Z, Lee ST (2006) Sphingobacterium composti sp. nov., a novel DNase-producing bacterium isolated from compost. J Microbiol Biotechnol 16:1728-1733

Tindall BJ (1990a) A comparative study of the lipid composition of Halobacterium saccharovorum from various sources. Syst Appl Microbiol 13:128-130

Tindall BJ (1990b) Lipid composition of Halobacterium lacusprofundi. FEMS Microbiol Lett 66:199-202

Tindall BJ, Sikorski J, Smibert RM, Kreig NR (2007) Phenotypic characterization and the principles of comparative systematics. In: Methods for general and molecular microbiology, 3rd edn, pp 330-393

Tóth Á, Baka E, Bata-Vidács I, Luzics S, Kosztik J, Tóth E, Kéki Z, Schumann P, Táncsics A, Nagy I, Sós E, Kukolya J (2017) Micrococcoides hystricis gen. nov., sp. nov., a novel member of the family Micrococcaceae, phylum Actinobacteria. Int J Syst Evol Microbiol 67:2758-2765

Vallenet D, Engelen S, Mornico D, Cruveiller S, Fleury L, Lajus A, Rouy Z, Roche D, Salvignol G, Scarpelli C, Médigue C (2009) MicroScope: a platform for microbial genome annotation and comparative genomics. Database J Biol Databases Curation 2009:21

van den Burg B (2003) Extremophiles as a source for novel enzymes. Curr Opin Microbiol 6:213-218

Ventosa A, Nieto JJ, Oren A (1998) Biology of moderately halophilic aerobic bacteria. Microbiol Mol Biol Rev 62:504-544
Xu L, Sun JQ, Wang LJ, Gao ZW, Sun LZ, Wu XL (2017) Sphingobacterium alkalisoli $\mathrm{sp}$. nov., isolated from a saline-alkaline soil. Int J Syst Evol Microbiol 67:1943-1948

Xu L, Dong Z, Fang L, Luo Y, Wei Z, Guo H, Zhang G, Gu YQ, Coleman-Derr D, Xia Q, Wang Y (2019) OrthoVenn2: a web server for whole-genome comparison and annotation of orthologous clusters across multiple species. Nucl Acids Res 47:W52-W58

Yabuuchi E, Kaneko T, Yano I, Moss CW, Miyoshi N (1983) Sphingobacterium gen. nov., Sphingobacterium spiritivorum comb. nov., Sphingobacterium multivorum comb. nov., Sphingobacterium mizutae sp. nov., and Flavobacterium indologenes sp. nov.: glucose-nonfermenting gramnegative rods in CDC groups IIK-2 and IIb. Int J Syst Bacteriol 33:580-598

Yin J, Chen JC, Wu Q, Chen GQ (2015) Halophiles, coming stars for industrial biotechnology. Biotechnol Adv 33:1433-1442

Yoo SH, Weon HY, Jang HB, Kim BY, Kwon SW, Go SJ, Stackebrandt E (2007) Sphingobacterium composti sp. nov., isolated from cotton-waste composts. Int J Syst Evol Microbiol 57:1590-1593

Publisher's Note Springer Nature remains neutral with regard to jurisdictional claims in published maps and institutional affiliations. 